\title{
Research
}

\section{Pastoralists' Perception and Ecological Knowledge on Savanna Ecosystem Dynamics in Semi-arid Botswana}

\author{
Olaotswe Kgosikoma $^{1,2}$, Witness Mojeremane $^{3}$ and Barbra A. Harvie $^{2}$
}

\begin{abstract}
We investigated vegetation dynamics in relation to livestock grazing as perceived by pastoral farmers in different regions of Botswana. A structured questionnaire was used to collect farmers' understanding of vegetation changes and causes within three different grazing lands. The pastoral farmers' description of dominant vegetation differed significantly both at the local and district level, which suggests that rangelands consist of patches dominated by different grasses and woody vegetation. Most pastoralists indicated that grass composition has undergone changes, and unpalatable grasses such as Aristida congesta and Megaloprotachne albescens are increasing. The different factors perceived by pastoral farmers to cause changes in vegetation composition included rainfall, overgrazing, and fire. Bush encroachment is considered to be more common in communal grazing land than in ranches. According to pastoral farmers, the ranching system is less degrading to the environment and more sustainable for livestock production than is communal grazing.
\end{abstract}

Key Words: communal grazing; indigenous ecological knowledge, livestock; ranching; rangeland degradation

\section{INTRODUCTION}

The savanna ecosystem is used largely for livestock grazing (Bagchi and Ritchie 2010), and prolonged overgrazing is associated with land degradation (Cheng et al. 2011). Overgrazing, which refers to the overutilization of grazing resources, by livestock promotes the increase in undesirable herbaceous plant species and bush encroachment, which are all indicators of rangeland degradation (Katjiua and Ward 2007). Degradation is the permanent loss of rangeland's biological or economic productivity in arid and semi-arid environments (Thomas 2008). The perspective and interpretations of rangeland degradation are highly controversial (Abel and Blaikie 1989, Dougill et al. 1999, Dahlberg 2000b, Skarpe 2000) and dominated by researchers, policy-makers, and extension workers (Dougill et al. 2002, Reed and Dougill 2010). Pastoralists' perception and ecological knowledge of vegetation changes are often ignored (Roba and Oba 2009) despite the debate about their role in rangeland degradation (Butt 2010). Yet, pastoralists are known to have extensive ecological knowledge (Berkes et al. 2000, Ladio and Lozada 2009) which could complement scientific knowledge (Oba and Kotile 2001) and contribute to improved understanding and sustainable management of savanna ecosystems (Reed et al. 2011).

In Botswana, livestock production is a dominant economic activity practiced in communal and ranching lands (Masike and Urich 2008). The grazing resources in communal land are managed as common pool resource in tribal land, and animals are allowed to roam freely around waterpoints. The ranching system is practiced in fenced freehold land and tribal land owned and managed by private individuals or groups. The general perception of policy-makers is that the ranching management system is environmentally sustainable and therefore a solution to overgrazing in communal land (Botswana Government 1975). Overgrazing is associated with communal grazing because there is no clear land tenure or property rights agreements that make it conducive for the farmers to invest in conservation of shared rangelands (Thomas 2008). However, that perspective is challenged by nonequilibrium theory, which attributes vegetation changes in arid environments mainly to stochastic abiotic factors, particularly rainfall variability (Ellis and Swift 1988, Westoby et al. 1989). This creates doubts about the relevance of rangeland carrying capacity, stocking rates, and grazing policy, which are considered to be key to sustainable management of ranches (Ellis and Swift 1988). Although both the communal and ranching lands are well researched (Thomas et al. 2000), there are limited long-term studies that compare vegetation conditions between grazing management systems. Given that pastoralists interact with their environment regularly and share ecological knowledge between generations (Roba and Oba 2009), they could provide a longterm ecological perspective of vegetation changes in rangelands and the underlying causes (Bart 2006), which is normally lacking in most ecological studies (Brook and McLachlan 2008, Knapp and Fernandez-Gimenez 2008).

Pastoral communities are known to have elaborate knowledge of plant species composition and palatability to grazing animals, and trends in vegetation change in response to factors such as rainfall variability and grazing pressure (Davis 2005, Oba and Kaitira 2006). This knowledge and perception has significant influence on the management strategies adopted to exploit a particular ecosystem (Ellis and Swift 1988). Hence, it is essential to understand how pastoral farmers perceive rangeland conditions and the extent of degradation in both communal grazing land and ranches. Common understanding 
Table 1. The biophysical features of the study sites.

\begin{tabular}{lcccc}
\hline \hline Site name & District & $\begin{array}{c}\text { Mean annual } \\
\text { precipitation } \\
(\mathrm{mm}) \\
(1988-2009)\end{array}$ & Soils & Vegetation \\
\hline Goodhope & Southern & 475 & Noncalcareous loam & Acacia giraffae tree savanna \\
Matlolakgang & Kweneng & 434 & Noncalcareous sand & Central Kalahari bush savanna \\
Xanagas & Gantsi & 368 & Calcareous & Northern Kalahari tree and bush savanna \\
\hline
\end{tabular}

of rangeland degradation by both researchers and pastoral communities is crucial for combating rural poverty and environmental degradation (Kessler and Stroosnijder 2010), and is relevant to all stakeholders.

Previous studies conducted in Botswana have provided broad knowledge of local perceptions of environmental degradation associated with dominant livelihoods such as arable farming and veld products exploitation (Chanda 1996, Ringrose et al. 1996). However, community-based ecological knowledge differs based on interests like veld products and grazing (Oba et al. 2008). We focus specifically on knowledge and perception of vegetation dynamics and livestock grazing in both communal grazing lands and ranches. Traditional ecological knowledge is unique to different places and communities (Fernandez-Gimenez 2000), and even to different individuals within a community. Therefore, examining the pastoralists' ecological knowledge under different cultural and environmental conditions is expected to provide a broader understanding of ecosystem dynamics. Our objectives are to use pastoral ecological knowledge to (i) characterize the composition of grass species, (ii) characterize the dynamics of woody vegetation, and (iii) compare the effects of rangeland management systems on vegetation and livestock production in different ecological systems.

\section{MATERIAL AND METHODS}

\section{Study area}

The study was carried out in three sites located at Xanagas, Matlolakgang, and Goodhope (Fig. 1). The three sites represented the ecological variation across the country. Three fenced ranches, one from each site, were randomly selected from a list of ranches used as monitoring sites in different regions of Botswana. Data were also collected from communal grazing lands close to selected ranches. The communal grazing land did not have well-defined boundaries and was shared by communities from several different villages. Subsequently, the sampling area for Xanagas included pastoral farmers from the villages of Karakubis and Charleshill, while the Matlolakgang sample area consisted of Ngware, Malwelwe, and Molepolole villages. In Goodhope, the sampled farmers included those from Sheep farm and Metlojane villages. The study sites also represented different ethnic groups (e.g.,
Bakgalagadi, Basarwa, Baherero, Bakwena, Barolong, and other Tswana tribes); therefore, the results are likely to have wide application regionally and nationally. The three study site areas were located in savanna biome but were characterized by different biophysical features (e.g., rainfall and soil type), as described in Table 1.

Fig. 1. Locations of the three study sites in Botswana (Matlolakgang is located between Malwele and Ngware).

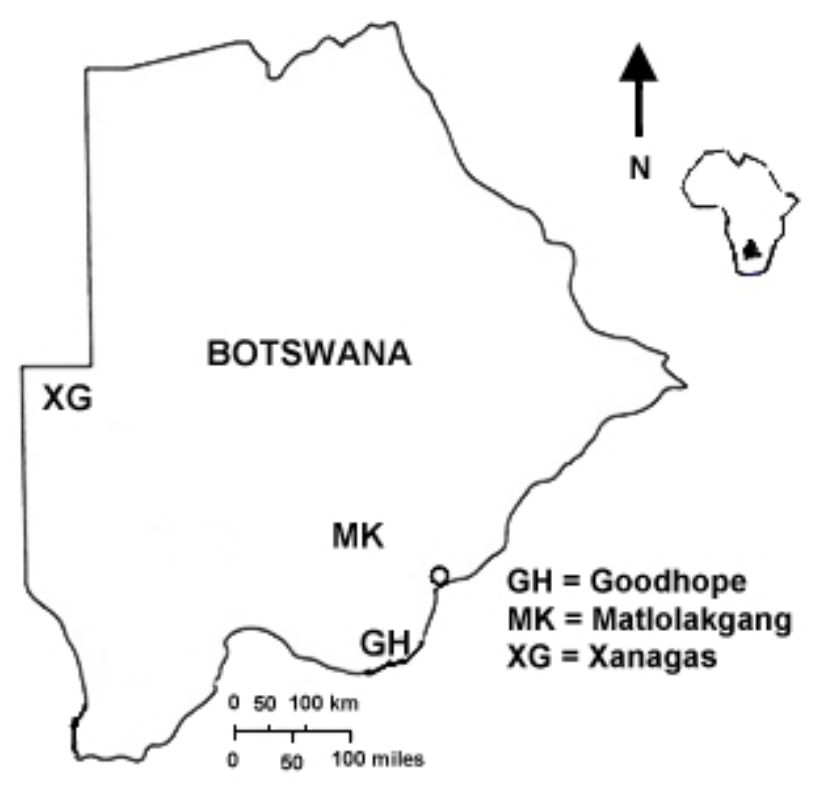

\section{Sampling and data collection}

Data on vegetation dynamics in grazing lands were collected between May and June 2009 using a structured questionnaire. This approach is increasingly being used by ecologists to investigate changes in ecological systems associated with human behavior (White et al. 2005). Rapid assessment interviews with local people are relatively inexpensive and provide reliable information on resource trends (Jones et al. 2008). Even though the structured questionnaire is not flexible enough to allow in-depth discussion of some topics, its use in this study was preferred to that of semi-structured interviews because it standardized the way respondents were asked 
questions by different interviewers in order to minimize sources of error (e.g., inter-interviewer variability) (Bryman 2004). The questionnaire consisted of both close- and openended questions, but open-ended questions were coded during data entry. The questionnaire was dominated by open-ended questions to allow respondents to express their knowledge of rangeland condition in their own terms, as suggested by Bryman (2004).

The interviews were conducted face-to-face with individual pastoral farmers using the national language of Botswana, Setswana, which is mostly understood throughout the country (Mbaiwa and Stronza 2011). A total of 125 respondents from the pastoral communities in the three study sites were selected: Goodhope $(n=38)$, Matlolakgang $(n=42)$, and Xanagas $(n$ $=45$ ). Initially, the target sample size per site was 50, but this was not achieved because some pastoralists were away from both villages and cattle-posts, where livestock are kept in communal land, during the survey period. There was no formal list of pastoral farmers at each site; therefore, either male or female respondents were selected from alternating households from a random starting point (household) to ensure that households had a fair chance of being selected irrespective of their social background.

The pastoralists had to characterize the grass composition within their grazing area by describing (i) dominant species, and (ii) grazing desirability or palatability of dominant grasses as very palatable, palatable, or unpalatable. Similar Setswana names are used for different grasses, so the validity of the results of this study was increased by asking pastoral farmers to describe species in detail or show enumerators the species in the field whenever the local name was not specific. The pastoralists also had to describe (iii) trends in individual grass species by indicating whether a particular species had increased (increasers), decreased (decreaser), or remained stable (stable) within the past five years or within historical knowledge. Other authors (Roba and Oba 2009) indicated that pastoral farmers commonly use terms such as increasing, not changing, or decreasing during assessment of species trends. Pastoralists were also asked whether grass composition had changed historically and what were the causal factors linked to the observed changes.

In order to characterize woody vegetation within their grazing lands, pastoralists were asked to describe (i) the dominant woody plant species, (ii) their trend as stable, increasing, or decreasing, and (iii) their suitability (palatability) to grazing animals as very palatable or not palatable. Pastoral farmers were also asked whether bush encroachment was a problem within their grazing lands, what its impact was, and what current management strategies were being used to address the problem. Woody plant species associated with bush encroachment were also identified by pastoralists. The association between rangeland degradation and grazing management systems was established by asking whether observed degradation was common in either communal or ranching grazing lands. The pastoralists were further asked to indicate whether the perceived changes in grass composition and bush encroachment were more pronounced in any particular grazing management system.

\section{Data analysis}

The collected data on rangeland condition were analyzed quantitatively using Statistical Package for the Social Sciences (SPSS 15). Cross-tabulation and Chi-square tests were used to determine differences between pastoralists' responses between sites. The response rates to some questions, such as plant palatability to livestock, were low to the extent that it was not possible to make comparisons between sites. In such cases, the responses were grouped together irrespective of study sites, and the general pattern was reported. A comparison between young ( $\leq 30$ years) and old pastoralists' perception of changes in grass composition and bush encroachment was determined using Chi-square tests.

\section{RESULTS}

\section{Grass compositions as perceived by pastoralists}

Pastoralists identified different grasses as dominant at the three sites (Table 2). However, Aristida congesta and Stipagrostis uniplumis were considered to be dominant by more than half of respondents in all three grazing lands, with $A$. congesta being identified as dominant by $97.4 \%$ and $88.9 \%$ of pastoralists at Goodhope and Xanagas, respectively. A significant proportion of pastoral farmers at Matlolakgang (81\%) identified Megaloprotachne albescens as a dominant grass species in their grazing area. All pastoralists at Goodhope mentioned Cynodon dactylon as an abundant grass species in their grazing lands. Most pastoralists classified only $C$. dactylon and Schmidtia pappophoroides as very palatable, while most of the dominant grasses were largely perceived as only moderately palatable for grazing. Among dominant grasses, $A$. congesta and $M$. albescens were mainly perceived as unpalatable for grazing.

The rangelands at Goodhope and Matlolakgang were mainly perceived to have undergone changes in grass composition (63\% and $73 \%$, respectively), which significantly differed with the perception of Xanagas pastoralists, who largely indicated that grass composition had not changed (53.3\%) $\left(\chi^{2}\right.$ $=22.3, P<0.001)$. This perception was consistent between younger ( $\leq 30$ years) and older pastoralists $\left(\chi^{2}=4.4, P>0.05\right)$, but a significant number of pastoralists at Goodhope (21.1\%) did not know whether grass composition had changed. The change in grass composition was characterized by an increase in unpalatable grasses, such as A. congesta and M. albescens, and a decline in moderately palatable grasses, such as Eragrostis pallens, Eragrostis rigidior, and S. uniplumis (Table 2). The changes in grass composition were mainly 
Table 2. Proportions of pastoral farmers who indicated that different grasses were dominant within their rangelands.

\begin{tabular}{|c|c|c|c|c|c|c|c|}
\hline \multirow[b]{2}{*}{ Scientific name } & \multirow[b]{2}{*}{ Local name } & \multirow{2}{*}{$\begin{array}{c}\text { Grazing } \\
\text { suitability } \\
\text { /trends } \dagger\end{array}$} & \multicolumn{3}{|c|}{$\%$ of respondents who named species as dominant } & \multirow[b]{2}{*}{$\chi^{2}$} & \multirow[b]{2}{*}{$P$ value } \\
\hline & & & $\begin{array}{c}\text { Goodhope } \\
(n=38)\end{array}$ & $\begin{array}{c}\text { Matlolakgang } \\
(n=42)\end{array}$ & $\begin{array}{c}\text { Xanagas } \\
(n=45) \\
\end{array}$ & & \\
\hline Aristida congesta & Seloka & $\mathrm{U} / \mathrm{I}$ & 97.4 & 52.4 & 88.9 & 28.5 & $* * *$ \\
\hline Cenchrus ciliaris & Mosekangwetsi & $\mathrm{P}$ & List of grasses & 0 & 2.2 & NA & NA \\
\hline Cynodon dactylon & Motlho & $\mathrm{V} / \mathrm{S}$ & 100.0 & 19.0 & 2.2 & 93.2 & $* * *$ \\
\hline Eragrostis pallens & Motsikiri & $\mathrm{P} / \mathrm{D}$ & 68.4 & 26.2 & 0 & 46.6 & $* * *$ \\
\hline Eragrostis rigidior & Rathethe & $\mathrm{P} / \mathrm{D}$ & 26.3 & 31.0 & 0 & 16.1 & $* * *$ \\
\hline Megaloprotachne albescens & Mohaha & $\mathrm{U} / \mathrm{I}$ & 0 & 81.0 & 0 & 92.3 & $* * *$ \\
\hline Schmidtia pappophoroides & Tshwang & $\mathrm{V}$ & 0 & 11.9 & 55.6 & 39.9 & $* * *$ \\
\hline Stipagrostis uniplumis & Tshikitshane & $\mathrm{P} / \mathrm{D}$ & 55.3 & 59.5 & 53.3 & 0.35 & NS \\
\hline Urochloa trichopus & Phoka & $\mathrm{P}$ & 0 & 2.4 & 55.6 & 51.6 & $* * *$ \\
\hline
\end{tabular}

attributed to rainfall variability (Table 3), especially at Goodhope $(63.2 \%)$ and Xanagas $(82.2 \%)$. Overgrazing was another perceived causal factor for changes in grass composition, particularly at Goodhope $(60.5 \%)$, though less so at Xanagas, where fire was suggested as a causal factor by $57.8 \%$ of respondents.

\section{Woody vegetation composition as perceived by pastoralists}

Pastoralists identified different woody plant species as dominant within their grazing lands, though Acacia species were abundant in all regions (Table 4). A few woody plants species, such as Acacia burkei (31\%) and Dichrostachys cinerea $(78.6 \%)$, were perceived to be dominant by pastoralists at Matlolakgang only, while Boscia albitrunca was considered to be dominant by $65.8 \%$ of pastoralists at Goodhope. Terminalia sericea was largely perceived to be dominant by pastoralists grazing in Matlolakgang $(83.3 \%)$ and Xanagas rangelands $(95.6 \%)$, both of which are located in sandy regions (Table 4). Pastoralists generally acknowledged the importance of woody vegetation as a browsing resource, though not all woody plants were identified as suitable for browsing (Table 4). B. albitrunca, dominant at Goodhope, was considered to be very suitable for browsing by $80.8 \%$ of pastoralists. Most dominant woody plant species were considered to be moderately desirable for browsing, with the exception of Acacia erioloba, which was largely perceived as unsuitable for browsing (64.3\%).

Bush encroachment was perceived as an environmental problem by the majority of both young ( $\leq 30$ years) and old pastoralists $\left(\chi^{2}=2.33, P>0.05\right)$ at all sites, though the perception differed significantly between sites $\left(\chi^{2}=9.94, P<\right.$ $0.01)$. Most pastoralists at Matlolakgang $(88.1 \%)$ considered their rangelands to be highly encroached by woody vegetation. Goodhope and Xanagas rangelands were perceived to be encroached by bushes by $68.4 \%$ and $57.8 \%$ of respondents, respectively. Most of the dominant woody plant species identified as encroachers were increasing in respective rangelands, with the exception of B. albitrunca and Ochna pulchra, which were largely considered to be declining in the rangelands (Table 4). D. cinerea was largely considered to be increasing in Matlolakgang rangelands (94.4\%).

The pastoralists' perceptions of the effect of bush encroachment on herbaceous vegetation at Goodhope, Matlolakgang, and Xanagas differed significantly $\left(\chi^{2}=15.3\right.$, $P<0.01)$. Most respondents at Goodhope (68.4\%), Xanagas $(66.7 \%)$, and Matlolakgang $(47.6 \%)$ indicated that bush encroachment had led to reduced primary grass production. However, some pastoralists, like $31.1 \%$ of the respondents at Xanagas, indicated that bush encroachment had no effect on grass productivity, while $28.6 \%$ of pastoralists at Matlolakgang indicated that they did not know the effects of bush encroachment on herbaceous vegetation. Most pastoral farmers $(80.8 \%)$ indicated that nothing was being done to mitigate bush encroachment, while only $14.4 \%$ of all pastoral farmers indicated that they were cutting down trees to control bush encroachment. Small proportions $(3.2 \%$ and $1.6 \%)$ of pastoral farmers indicated that they practiced rotational grazing and fire (burning) to control bush encroachment, respectively.

\section{Effects of rangeland management systems on vegetation and livestock production}

The pastoral farmers' perception of the effect of rangeland management systems on vegetation changes differed both locally and between sites. The changes in grass species composition were considered to be more pronounced in communal grazing land than in ranches, especially at Matlolakgang (Fig. 2a). But many pastoralists, particularly at Xanagas (31.1\%), indicated that changes in grass composition were also common under the ranching system, while others indicated that both management systems were affected similarly (Fig. 2a). The pastoral farmers' perception also differed strongly on the occurrence of bush encroachment in 
Table 3. Factors considered to have contributed to changes in the composition of grasses.

\begin{tabular}{|c|c|c|c|c|c|c|}
\hline \multirow[b]{2}{*}{ Factors } & \multirow[b]{2}{*}{$\begin{array}{c}\text { Overall \% of } \\
\text { responses }\end{array}$} & \multicolumn{3}{|c|}{$\%$ of respondents at different sites } & \multirow[b]{2}{*}{$\chi^{2}$} & \multirow[b]{2}{*}{$P$ value } \\
\hline & & $\begin{array}{c}\text { Goodhope } \\
(n=38)\end{array}$ & $\begin{array}{c}\text { Matlolakgang } \\
(n=42)\end{array}$ & $\begin{array}{l}\text { Xanagas } \\
(n=45) \\
\end{array}$ & & \\
\hline Fire & 25.6 & 7.9 & 7.1 & 57.8 & 38.2 & $* * *$ \\
\hline Overgrazing & 46.5 & 60.5 & 23.8 & 15.6 & 21.1 & $* * *$ \\
\hline$\underline{\text { Rainfall }}$ & 59.2 & 63.2 & 31.0 & 82.2 & 24.0 & $* * *$ \\
\hline
\end{tabular}

$+* * *=P<0.001$

both communal and ranching rangelands between the study sites $\left(\chi^{2}=30.8, P<0.001\right)$. Bush encroachment was considered to be a problem in communal grazing areas at all sites (Fig. 2b), though some pastoralists, particularly in Xanagas $(37.8 \%)$, also reported an increase in woody vegetation under the ranching system. However, $36.8 \%$ of pastoralists at Goodhope did not know whether bush encroachment was a problem in either of the two systems. Pastoralists largely considered communal grazing land to be more prone to overgrazing $(70.4 \%)$ than were ranches $(5.6 \%)$, while $20.8 \%$ reported that both systems had a similar degrading effect on the environment. Ranches were considered by $74.4 \%$ of respondents to be more appropriate for livestock production than was a communal grazing system. About $18.4 \%$ of the pastoral farmers perceived both rangeland management systems to be more sustainable for livestock production, while only $7.2 \%$ favored the communal grazing system.

\section{DISCUSSION}

The results of this study show that most pastoral farmers are knowledgeable about grass composition, palatable plant species, and trends in vegetation and their causes within their local environment, as suggested in the literature (FernandezGimenez 2000). However, pastoralists' knowledge is not uniformly shared within or between pastoral communities, as indicated by the lack of agreement on some aspects of vegetation dynamics, which is consistent with other studies (Knapp and Fernandez-Gimenez 2008, Kassam 2009).

\section{Grass compositions as perceived by pastoralists}

Pastoralists' responses showed differences in dominant grass species in their respective grazing lands, even at the local level, which suggests that rangelands are spatially heterogeneous. The heterogeneity of the grass composition across the landscape was probably influenced by variability in soil characteristics, grazing pressure (Cole and Brown 1976, Roba and Oba 2009), and rainfall (Thomas and Twyman 2004), as observed during the ecological assessment (Kgosikoma 2011). The dominance of $A$. congesta, which is an increaser II species
Fig. 2. Grass composition change (a) and bush encroachment (b) in relation to grazing management systems as percieved by pastoralists at Goodhope (GH), Matlolakgang (MK), and Xanagas (XG) (Missing columns $=$ no respondents).

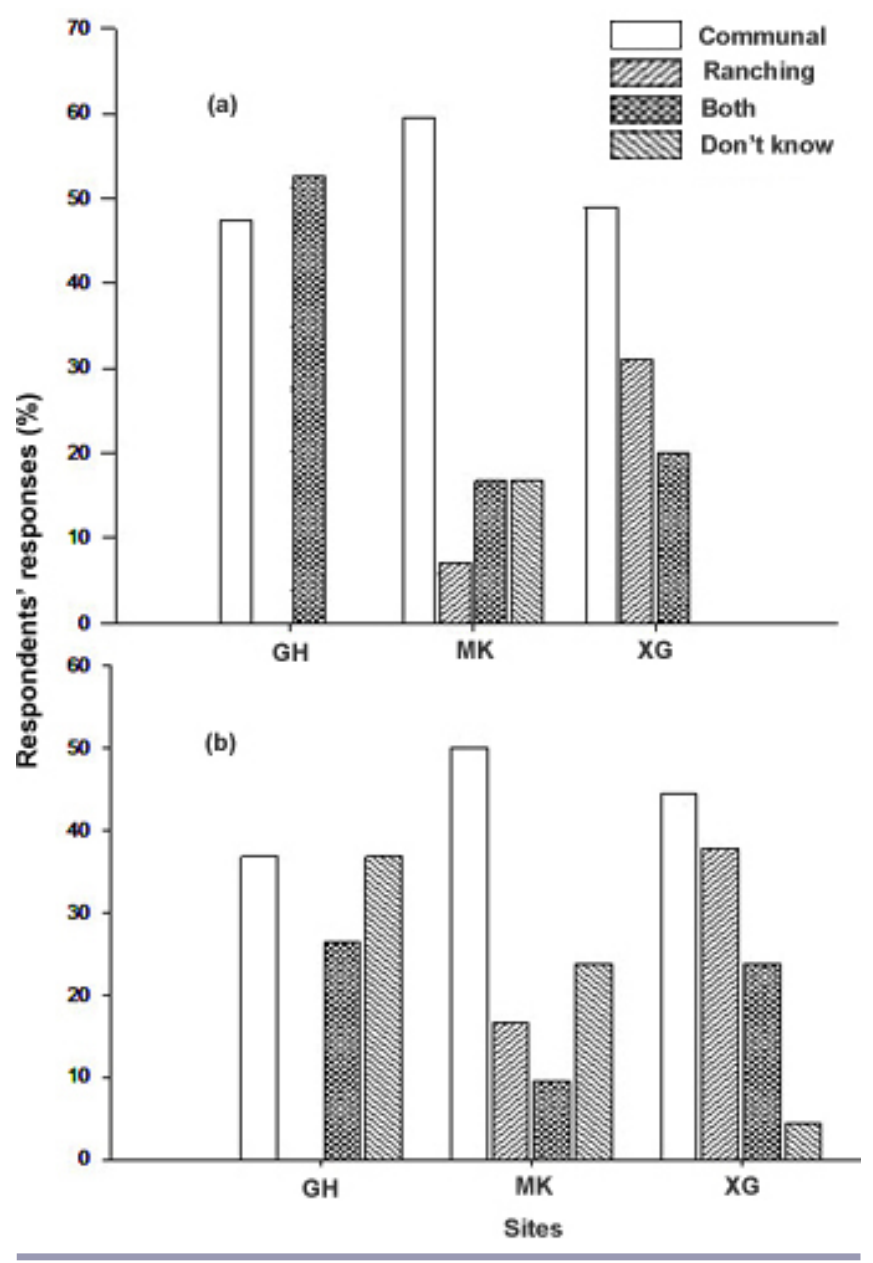


Table 4. Proportions of farmers who indicated that different woody plant species were dominant within their grazing areas.

\begin{tabular}{|c|c|c|c|c|c|c|c|}
\hline \multirow[b]{2}{*}{ Scientific name } & \multirow[b]{2}{*}{ Local name } & \multirow[b]{2}{*}{$\begin{array}{c}\text { Browsing } \\
\text { suitability } \\
\text { /trends } \dagger\end{array}$} & \multicolumn{3}{|c|}{$\%$ of presence response at different sites } & \multirow[b]{2}{*}{$\chi^{2}$} & \multirow[b]{2}{*}{$P$ value $\ddagger$} \\
\hline & & & $\begin{array}{c}\text { Goodhope } \\
(n=38)\end{array}$ & $\begin{array}{l}\text { Matlolakgang } \\
\quad(n=42)\end{array}$ & $\begin{array}{c}\text { Xanagas } \\
(n=45)\end{array}$ & & \\
\hline Acacia burkei & Mokgwa & $\mathrm{S}$ & 0 & 31 & 0 & NA & NA \\
\hline Acacia erioloba & Mogotlho & $\mathrm{U} / \mathrm{S}^{*}$ & 86.8 & 23.8 & 28.9 & 39.3 & $* * *$ \\
\hline Acacia hebeclada & Sekhi & $\mathrm{S} / \mathrm{I}$ & 73.7 & 4.8 & 68.9 & 49.3 & $* * *$ \\
\hline Acacia mellifera & Mongana & $\mathrm{S} / \mathrm{I}$ & 63.2 & 14.3 & 75.6 & 35.8 & $* * *$ \\
\hline Acacia tortilis & Mosu & $\mathrm{S} / \mathrm{I}$ & 97.4 & 14.3 & 0 & 97.9 & $* * *$ \\
\hline Boscia albitrunca & Motlope & $\mathrm{V} / \mathrm{D}$ & 65.8 & 16.7 & 0 & 49.5 & $* * *$ \\
\hline Dichrostachys cinerea & Moselesele & $\mathrm{S} / \mathrm{I}$ & 0 & 78.6 & 0 & 88.6 & $* * *$ \\
\hline Grewia flava & Moretlwa & $\mathrm{S} / \mathrm{I}$ & 92.1 & 21.4 & 71.1 & 44.9 & $* * *$ \\
\hline Lonchocarpus nelsii & Mhata & $\mathrm{V}$ & 0 & 47.6 & 0 & 47.1 & $* * *$ \\
\hline Ochna pulchra & Monyelenyele & & 0 & 9.5 & 0 & NA & NA \\
\hline Terminalia sericea & Mogonono & $\mathrm{S} / \mathrm{I}$ & 21.1 & 83.3 & 95.6 & 54.5 & $* * *$ \\
\hline Ziziphus mucronata & Mokgalo & $\mathrm{V} / \mathrm{I}$ & 52.6 & 7.1 & 77.8 & 44.4 & $* * *$ \\
\hline
\end{tabular}

$\dagger(\mathrm{U})$ unsuitable, $\mathrm{S}$ (suitable), (V) very suitable, (I) increasing, (S*) stable, (D) decreasing (based on majority of respondents)

$\$ \mathrm{NA}=>20 \%$ cells have expected values less than $5 ; * * *=P<0.001$

(Trollope et al. 1989), probably indicates that overgrazing is occurring in both the ranches and communal grazing land due to keeping a high number of livestock that exceeds the rangeland's carrying capacity. This is further supported by the presence of few very palatable grass species, which may suggest that these species are overgrazed, as reported in other regions of Botswana (Reed et al. 2008).

The pastoralists, particularly at Goodhope and Matlolakgang, indicated that the composition of grass species had changed such that palatable grass species such as $E$. rigidior and $S$. uniplumis were being replaced by unpalatable species such as A. congesta and M. albescens, which may be an indication of overgrazing, as indicated in other studies (du Plessis et al. 1998, Roba and Oba 2009). However, the distribution of grasses could also be influenced by species' ability to adapt to local environmental conditions such as moisture availability and soil fertility (Muhumuza and Byarugaba 2009); therefore, differences in the composition of dominant grass species and trends could also be attributed to variability in rainfall and soil fertility between the three sites.

In fact, the pastoralists attributed changes in grass composition mainly to rainfall variability, which is consistent with the nonequilibrium explanation (Ellis and Swift 1988, Westoby et al. 1989). This is supported by studies conducted in the northeast part of Botswana, where local communities indicated that changes in their ecosystem were caused by variable rainfall (Chanda 1996, Dahlberg 2000a). Overgrazing was another factor perceived by pastoralists to contribute towards changes in the grass species composition, though more than $50 \%$ of them did not associate vegetation changes with livestock populations. According to Chanda (1996), pastoral farmers tend to evade blame for overgrazing, and this could explain why most of the respondents failed to mention overgrazing as a cause of vegetation changes in this study. Although fire is also known to influence the composition of savanna vegetation (Furley et al. 2008, Devineau et al. 2010), it was hardly mentioned by respondents in this study, except at Xanagas. The possible explanation could be that the laws of Botswana do not allow the use of fire as a management tool in rangelands. In addition, the government has invested in the construction and maintenance of firebreaks to reduce fire incidences in rangelands. The other possible explanation is that livestock grazing removes fuel load, which in turn reduces the possibility of fire (van Langevelde et al. 2003).

\section{Woody vegetation composition as perceived by pastoralists}

The perceived dominant woody plant species differed between the three study sites, although Acacia mellifera and Grewia flava were widely distributed in all three sites. The variations in the composition of dominant woody plants could also be explained by landscape patches and heterogeneity both within each site and between sites, which is a function of rainfall variability (Sankaran et al. 2005) and soil fertility (Boone 2005, Tefera et al. 2008). Pastoralists' descriptions of dominant woody vegetation may suggest that the landscape consists of patches of land highly encroached or not encroached, as suggested by patch dynamics (Meyer et al. 2009).

The observation by pastoralists that bush encroachment was occurring was further validated during ecological assessment, particularly at Matlolakgang and Xanagas (Kgosikoma et al. 2012). Most of the woody plant species, such as A. mellifera, $G$. flava, and D. cinerea, that were perceived by pastoralists to be dominant have been associated with bush encroachment throughout the Kalahari ecosystem (Tews et al. 2004, Thomas and Twyman 2004), and therefore indicate that these grazing 
lands are overgrazed (Reed et al. 2008). The abundance of $B$. albitrunca at Goodhope rangelands may indicate that part of those rangelands are in good condition and are not overgrazed, as suggested by ecologists (Reed et al. 2008). Furthermore, the pastoral communities indicated that the increase in encroacher woody plants in rangelands suppresses grass productivity, which reduces grazing area for livestock. This is in agreement with results of studies conducted in other parts of Botswana (Dougill et al. 1999) and elsewhere (Angassa and Oba 2008b), which also show that bush encroachment is common in rangelands. Bush encroachment therefore threatens the livelihoods of pastoral communities (Angassa and Oba 2008a), especially in developing countries.

Despite the negative impact of bush encroachment on grazing land, pastoral farmers also indicated that woody plants were important as feed for livestock. They indicated that the increase in woody plants in rangelands was beneficial as an essential fodder resource that supports livestock, as suggested by Moleele (1998) and Dougill et al. (1999). Woody plants such as B. albitrunca, G. flava, and D. cinerea are recognized as an important component of cattle diet, especially during dry periods, because of their nutrient-rich pods and their ability to flush early after the dry season, which is in agreement with observations by Moleele (1998). In addition, most of the woody plant species considered to be suitable for browsing by pastoral farmers in the this study are leguminous species, which are likely to have a high crude protein content, probably due to their ability to fix atmospheric nitrogen (Moleele 1998). The importance of woody plants as a fodder source could be the reason why most pastoralists in Botswana are currently not controlling bush encroachment. However, the consumption of the pods of woody plants by livestock is likely to be a mechanism that enhances bush encroachment through seed dispersal (Tews et al. 2004). It is, therefore, essential for pastoralists and researchers to work together for bush thickening to be controlled in savanna ecosystems.

\section{Effects of rangeland management systems on vegetation and livestock production}

The effects of communal and ranching management on vegetation change were as debatable among pastoralists as they are among ecologists. However, a significant number of pastoralists in the this study indicated that changes in grass composition and bush encroachment were more pronounced in communal grazing land, although the ranching system was also affected. Pastoralists acknowledged that the communal grazing lands are more degraded than ranches. In contrast, a long-term satellite-based assessment of rangeland conditions in Botswana showed that ranches were more degraded than other land uses, including communal grazing land (Vanderpost et al. 2011). But, ecological assessment indicated that bush encroachment was high in both ranches and communal grazing lands (Kgosikoma et al. 2012), as suggested by some pastoralists. In a study conducted in Ethiopia, the Borana pastoralists indicated that changing from pastoral land use to ranches and private enclosures was a major cause of bush encroachment in rangelands (Dalle et al. 2006, Angassa and Oba 2008b), which contradicts the perception of pastoralists in the current study. Similarly, another study conducted in the Republic of South Africa showed that there was less bush encroachment in communal grazing areas because woody plants are cut and utilized by local communities (Wigley et al. 2009). The Botswana pastoralists' perception that ranches promote rangeland conservation could probably have been influenced by the Tribal Grazing Land Policy (Botswana Government 1975) promoted by the government of Botswana through its extension services, which promote ranching as sustainable grazing land use.

Most pastoralists indicated that the ranching management system was more sustainable for livestock production. This could be attributed partly to dual grazing rights because those allocated ranches are also allowed to use communal grazing land (Tsimako 1991). Hence, most pastoralists prefer to have ranches because this allows them to increase their herd sizes, but their management does not necessarily change to promote rangeland conservation (Motlopi 2006). Unlike the Masaai of Kenya and Borana of Ethiopia, pastoralists in Botswana no longer practice livestock herding (Reed et al. 2008) and are therefore likely to lose livestock in communal grazing land as animals go astray. Therefore, fenced ranches provide a more secure alternative for rearing livestock, especially since livestock owners spend more time away from the farm. However, privatization of a common-pool resource such as communal rangelands by absentee landowners threatens both the sustainability of ecosystems and the livelihood of local communities (Altrichter and Basurto 2008). It is therefore possible that pastoral farmers of Botswana are unaware of the implications of privatization of rangeland, which leads to shrinkage of communal grazing land.

\section{CONCLUSION}

Pastoralists were knowledgeable about vegetation changes in their grazing land, though ecological knowledge was not uniformly shared. Their rangeland assessment indicated that savannas are highly heterogeneous spatially, and are dominated by different grasses and woody plant species. Yet, loss of palatable grass and bush encroachment was common in most grazing lands, which indicates that rangeland degradation is occurring in some patches of grazing savanna. The pastoral communities largely attributed changes in grass composition to rainfall variability, though overgrazing and fire were also mentioned. The pastoralists' perception is that bush encroachment negatively affects livestock production by suppressing grass productivity but also contributes positively as a valuable feed resource, particularly during the dry period. Pastoralists largely associated rangeland degradation with communal grazing lands, though some indicated that ranching lands were similarly affected. The results showed that 
pastoralists' knowledge could complement scientific knowledge and improve our understanding of savanna ecosystems. Hence, participation of pastoral communities is essential for monitoring rangeland conditions, and they should work with researchers and policy-makers to control bush encroachment.

Responses to this article can be read online at:

http://www.ecologyandsociety.org/issues/responses. $\mathrm{php} / 5247$

\section{Acknowledgments:}

The authors are thankful to the Commonwealth Scholarship and School of Geosciences (University of Edinburgh) for funding this research. The Department of Agricultural Research (Government of Botswana) is acknowledged for providing transport during fieldwork. We are also grateful to Mr. Andrew Moroka, Mr. K. Dintwe, field assistants, and pastoral farmers for their support and participation. We also thank the reviewers for their comments, which significantly improved this article.

\section{LITERATURE CITED}

Abel, N. O. J., and P. M. Blaikie. 1989. Land degradation, stocking rates and conservation policies in the communal rangelands of Botswana and Zimbabwe. Land Degradation \& Development 1:101-123.

Altrichter, M., and X. Basurto. 2008. Effects of land privatisation on the use of common-pool resources of varying mobility in the Argentine Chaco. Conservation \& Society 6:154-165. http://dx.doi.org/10.4103/0972-4923.49209

Angassa, A., and G. Oba. 2008a. Effects of management and time on mechanisms of bush encroachment in southern Ethiopia. African Journal of Ecology 46:186-196. http://dx. doi.org/http://dx.doi.org/10.1007/s10745-007-9156-Z

Angassa, A., and G. Oba. 2008b. Herder perceptions on impacts of range enclosures, crop farming, fire ban and bush encroachment on the rangelands of Borana, Southern Ethiopia. Human Ecology 36:201-215.

Bagchi, S., and M. E. Ritchie. 2010. Introduced grazers can restrict potential soil carbon sequestration through impacts on plant community composition. Ecology Letters 13:959-968.

Bart, D. 2006. Integrating local ecological knowledge and manipulative experiments to find the causes of environmental change. Frontiers in Ecology and the Environment 4:541-546. http://dx.doi.org/10.1890/1540-9295(2006)4[541:ILEKAM]2.0. $\mathrm{CO} ; 2$
Berkes, F., J. Colding, and C. Folke. 2000. Rediscovery of traditional ecological knowledge as adaptive management. Ecological Applications 10:1251-1262. http://dx.doi. org/10.1890/1051-0761(2000)010[1251:ROTEKA]2.0.CO;2

Boone, R. B. 2005. Quantifying changes in vegetation in shrinking grazing areas in Africa. Conservation and Society 3.

Botswana Government. 1975. National policy on tribal grazing land. Government printer, Gaborone, Botswana.

Brook, R., and S. McLachlan. 2008. Trends and prospects for local knowledge in ecological and conservation research and monitoring. Biodiversity and Conservation 17:3501-3512. http://dx.doi.org/10.1007/s10531-008-9445-X

Bryman, A. 2004. Social research methods. Oxford University Press, New York, USA.

Butt, B. 2010. Pastoral resource access and utilization: quantifying the spatial and temporal relationships between livestock mobility, density and biomass availability in southern Kenya. Land Degradation \& Development 21:520 539. http://dx.doi.org/10.1002/ldr.989

Chanda, R. 1996. Human perceptions of environmental degradation in a part of the Kalahari ecosystem. GeoJournal 39:65-71. http://dx.doi.org/10.1007/BF00174930

Cheng, Y., M. Tsubo, T. Y. Ito, E. Nishihara, and M. Shinoda. 2011. Impact of rainfall variability and grazing pressure on plant diversity in Mongolian grasslands. Journal of Arid Environments 75:471-476. http://dx.doi.org/10.1016/j. jaridenv.2010.12.019

Cole, M. M., and R. C. Brown. 1976. The vegetation of the Ghanzi area of western Botswana. Journal of Biogeography 3:169-196. http://dx.doi.org/10.2307/3038009

Dahlberg, A. C. 2000a. Interpretations of environmental change and diversity: a critical approach to indications of degradation - the case of Kalakamate, northeast Botswana. Land Degradation \& Development 11:549-562. http://dx.doi. org/http://dx.doi.org/10.1002/1099-145X(200011/12)11:6<549:: AID-LDR413>3.0.CO;2-5

Dahlberg, A. C. 2000b. Vegetation diversity and change in relation to land use, soil and rainfall - a case study from NorthEast District, Botswana. Journal of Arid Environments 44:1940. http://dx.doi.org/http://dx.doi.org/10.1006/jare.1999.0566

Dalle, G., B. L. Maass, and J. Isselstein. 2006. Encroachment of woody plants and its impact on pastoral livestock production in the Borana lowlands, southern Oromia, Ethiopia. African Journal of Ecology 44:237-246. http://dx.doi.org/10.1111/ j.1365-2028.2006.00638.x

Davis, D. K. 2005. Indigenous knowledge and the desertification debate: problematising expert knowledge in 
North Africa. Geoforum 36:509-524. http://dx.doi. org/10.1016/j.geoforum.2004.08.003

Devineau, J.-L., A. Fournier, and S. Nignan. 2010. Savanna fire regimes assessment with MODIS fire data: their relationship to land cover and plant species distribution in western Burkina Faso (West Africa). Journal of Arid Environments 74:1092-1101. http://dx.doi.org/10.1016/j. jaridenv.2010.03.009

Dougill, A. J., D. S. G. Thomas, and A. L. Heathwaite. 1999. Environmental change in the Kalahari: integrated land degradation studies for nonequilibrium dryland environments. Annals of the Association of American Geographers 89:420 442. http://dx.doi.org/10.1111/0004-5608.00156

Dougill, A. J., C. Twyman, D. S. G. Thomas, and D. Sporton. 2002. Soil degradation assessment in mixed farming systems of southern Africa: use of nutrient balance studies for participatory degradation monitoring. Geographical Journal 168:195-210. http://dx.doi.org/10.1111/1475-4959.00048

du Plessis, W. P., G. J. Bredenkamp, and W. S. W. Trollope. 1998. Development of a technique for assessing veld condition in Etosha National Park, Namibia, using key herbaceous species. Koedoe 41:19-29. http://dx.doi.org/http://dx.doi. org/10.4102/koedoe.v41i1.242

Ellis, J.E., and D. M. Swift. 1988. Stability of African pastoral ecosystems: alternate paradigms and implications for development. Journal of Range Management 41:450-459. http://dx.doi.org/10.2307/3899515

Fernandez-Gimenez, M. E. 2000. The role of Mongolian nomadic pastoralists' ecological knowledge in rangeland management. Ecological Applications 10:1318-1326. http:// dx.doi.org/10.1890/1051-0761(2000)010[1318:TROMNP]2.0. $\mathrm{CO} ; 2$

Furley, P. A., R. M. Rees, C. M. Ryan, and G. Saiz. 2008. Savanna burning and assessment of long-term fire experiments with particular reference to Zimbabwe. Progress in Physical Geography 32:611-634. http://dx.doi. org/10.1177/0309133308101383

Jones, J. P. G., M. M. Andriamarovololona, N. Hockley, J. M. Gibbons, and E. J. Milner-Gulland. 2008. Testing the use of interviews as a tool for monitoring trends in the harvesting of wild species. Journal of Applied Ecology 45:1205-1212. http://dx.doi.org/10.1111/j.1365-2664.2008.01487.x

Kassam, K.-A. 2009. Viewing change through the prism of indigeneous human ecology: findings from the Afghan and Tajik Pamirs. Human Ecology 37:677-690. http://dx.doi. org/10.1007/s10745-009-9284-8

Katjiua, M., and D. Ward. 2007. Pastoralists' perceptions and realities of vegetation change and browse consumption in the northern Kalahari, Namibia. Journal of Arid Environments 69:716-730. http://dx.doi.org/10.1016/j.jaridenv.2006.11.010

Kessler, A., and L. Stroosnijder. 2010. Debating land degradation: strategy development for Bolivian mountain valleys. Land Degradation \& Development 21:480-483. http://dx.doi.org/10.1002/ldr.986

Kgosikoma, O. E. 2011. Understanding the savanna dynamics in relation to rangeland management systems and environmental conditions in semi-arid Botswana. Dissertation. University of Edinburgh, Edinburgh, Scotland.

Kgosikoma, O. E., B. A. Harvie, and W. Mojeremane. 2012. Bush encroachment in relation to rangeland management systems and environmental conditions in Kalahari ecosystem of Botswana. African Journal of Agricultural Research 7:2313-2319.

Knapp, C. N., and M. Fernandez-Gimenez. 2008. Knowing the land: a review of local knowledge revealed in ranch memoirs. Rangeland Ecology \& Management 61:148-155. http://dx.doi.org/10.2111/07-088.1

Ladio, A. H., and M. Lozada. 2009. Human ecology, ethnobotany and traditional practices in rural populations inhabiting the Monte region: resilience and ecological knowledge. Journal of Arid Environments 73:222-227. http:// dx.doi.org/10.1016/j.jaridenv.2008.02.006

Masike, S., and P. Urich. 2008. Vulnerability of traditional beef sector to drought and the challenges of climate change: the case of Kgatleng District, Botswana. Journal of Geography and Regional Planning 1:012-018.

Mbaiwa, J. E., and A. L. Stronza. 2011. Changes in resident attitudes towards tourism development and conservation in the Okavango Delta, Botswana. Journal of Environmental Management 92:1950-1959. http://dx.doi.org/10.1016/j. jenvman.2011.03.009

Meyer, K. M., K. Wiegand, and D. Ward. 2009. Patch dynamics integrate mechanisms for savanna tree-grass coexistence. Basic and Applied Ecology 10:491-499. http:// dx.doi.org/10.1016/j.baae.2008.12.003

Moleele, N. M. 1998. Encroacher woody plant browse as feed for cattle. Cattle diet composition for three seasons at Olifants Drift, south-east Botswana. Journal of Arid Environments 40:255-268. http://dx.doi.org/10.1006/jare.1998.0450

Motlopi, K. 2006. Privatisation of rangelands, ranch development, management and equity: the case of area 4B, Botswana. Norwegian University of Life Sciences, Aas, Norway.

Muhumuza, M., and D. Byarugaba. 2009. Impact of land use on the ecology of uncultivated plant species in the Rwenzori mountain range, mid western Uganda. African Journal of 
Ecology 47:614-621. http://dx.doi.org/10.1111/ j.1365-2028.2009.01033.x

Oba, G., P. Byakagaba, and A. Angassa. 2008. Participatory monitoring of biodiversity in East African grazing lands. Land Degradation \& Development 19:636-648. http://dx.doi. org/10.1002/ldr.867

Oba, G., and L. M. Kaitira. 2006. Herder knowledge of landscape assessments in arid rangelands in northern Tanzania. Journal of Arid Environments 66:168-186. http:// dx.doi.org/10.1016/j.jaridenv.2005.10.020

Oba, G., and D. G. Kotile. 2001. Assessments of landscape level degradation in southern Ethiopia: pastoralists versus ecologists. Land Degradation \& Development 12:461-475. http://dx.doi.org/10.1002/ldr.463

Reed, M. S., M. Buenemann, J. Atlhopheng, M. AkhtarSchuster, F. Bachmann, G. Bastin, H. Bigas, R. Chanda, A. J. Dougill, W. Essahli, A. C. Evely, L. Fleskens, N. Geeson, J. H. Glass, R. Hessel, J. Holden, A. A. R. Ioris, B. Kruger, H. P. Liniger, W. Mphinyane, D. Nainggolan, J. Perkins, C. M. Raymond, C. J. Ritsema, G. Schwilch, R. Sebego, M. Seely, L. C. Stringer, R. Thomas, S. Twomlow, and S. Verzandvoort. 2011. Cross-scale monitoring and assessment of land degradation and sustainable land management: a methodological framework for knowledge management. Land Degradation \& Development 22:261-271. http://dx.doi. org/10.1002/ldr.1087

Reed, M. S., and A. J. Dougill. 2010. Linking degradation assessment to sustainable land management: a decision support system for Kalahari pastoralists. Journal of Arid Environments 74:149-155. http://dx.doi.org/10.1016/j. jaridenv.2009.06.016

Reed, M. S., A. J. Dougill, and T. R. Baker. 2008. Participatory indicator development: What can ecologists and local communities learn from each other? Ecological Applications 18:1253-1269. http://dx.doi.org/http://dx.doi.org/10.1890/07-0519.1

Ringrose, S., R. Chanda, M. Nkambwe, and F. Sefe. 1996. Environmental change in the mid-Boteti area of north-central Botswana: biophysical processes and human perceptions. Environmental Management 20:397-410. http://dx.doi. org/10.1007/BF01203847

Roba, H. G., and G. Oba. 2009. Community participatory landscape classification and biodiversity assessment and monitoring of grazing lands in northern Kenya. Journal of Environmental Management 90:673-682. http://dx.doi. org/10.1016/j.jenvman.2007.12.017

Sankaran, M., N. P. Hanan, R. J. Scholes, J. Ratnam, D. J. Augustine, B. S. Cade, J. Gignoux, S. I. Higgins, X. Le Roux, F. Ludwig, J. Ardo, F. Banyikwa, A. Bronn, G. Bucini, K. K. Caylor, M. B. Coughenour, A. Diouf, W. Ekaya, C. J. Feral,
E. C. February, P. G. H. Frost, P. Hiernaux, H. Hrabar, K. L. Metzger, H. H. T. Prins, S. Ringrose, W. Sea, J. Tews, J. Worden, and N. Zambatis. 2005. Determinants of woody cover in African savannas. Nature 438:846-849. http://dx.doi. org/10.1038/nature04070

Skarpe, C. 2000. Desertification, no-change or alternative states: Can we trust simple models on livestock impact in dry rangelands? Applied Vegetation Science 3:261-268. http://dx. doi.org/http://dx.doi.org/10.2307/1479005

Tefera, S., B. J. Dlamini, and A. M. Dlamini. 2008. Dynamics of savannas in Swaziland: enchroachment of woody plants in relation to land use and soil classes and indigenous knowledge on plants utilization. Research Journal of Botany 3:49-64. http://dx.doi.org/10.3923/rjb.2008.49.64

Tews, J., F. Schurr, and F. Jeltsch. 2004. Seed dispersal by cattle may cause shrub encroachment of Grewia lava on southern Kalahari rangelands. Applied Vegetation Science 7:89-102.

Thomas, D. S. G., D. Sporton, and J. Perkins. 2000. The environmental impact of livestock ranches in the Kalahari, Botswana: natural resource use, ecological change and human response in a dynamic dryland system. Land Degradation \& Development 11:327-341.

Thomas, D. S. G., and C. Twyman. 2004. Good or bad rangeland? Hybrid knowledge, science, and local understandings of vegetation dynamics in the Kalahari. Land Degradation \& Development 15:215-231. http://dx.doi. org/10.1002/ldr.610

Thomas, R. J. 2008. 10th anniversary review: addressing land degradation and climate change in dryland agroecosystems through sustainable land management. Journal of Environmental Monitoring 10:595-603. http://dx.doi. org/10.1039/b801649f

Trollope, W. S. W., A. L. F. Potgieter, and N. Zambatis. 1989. Assessing veld condition in the Kruger National Park South Africa using key grass species. Koedoe 32:67-94. http://dx. doi.org/10.4102/koedoe.v32i1.465

Tsimako, B., 1991. The Tribal Grazing Land Policy (TGLP) ranches performance to date. Agricultural Planning and Statistics, Gaborone, Botswana.

Vanderpost, C., S. Ringrose, W. Matheson, and J. Arntzen. 2011. Satellite based long-term assessment of rangeland condition in semi-arid areas: an example from Botswana. Journal of Arid Environments 75:383-389. http://dx.doi. org/10.1016/j.jaridenv.2010.11.002

van Langevelde, F., C. A. D. M. van de Vijver, L. Kumar, J. van de Koppel, N. de Ridder, J. van Andel, A. K. Skidmore, J. W. Hearne, L. Stroosnijder, W. J. Bond, H. H. T. Prins, and M. Rietkerk. 2003. Effects of fire and herbivory on the stability 
of savanna ecosystems. Ecology 84:337-350. http://dx.doi. org/10.1890/0012-9658(2003)084[0337:EOFAHO]2.0.CO;2

Westoby, M., B. Walker, and I. Noy-meir. 1989. Opportunistic management for rangelands not at equilibrium. Journal of Range Management 42:266-274. http://dx.doi.org/10.2307/3899492

White, P. C. L., N. V. Jennings, A. R. Renwick, and N. H. L. Baker. 2005. Questionnaires in ecology: a review of past use and recommendations for best practice. Journal of Applied Ecology 42:421-430. http://dx.doi.org/10.1111/

j.1365-2664.2005.01032.x

Wigley, B. J., W. J. Bond, and M. T. Hoffman. 2009. Bush encroachment under three contrasting land-use practices in a mesic South African savanna. African Journal of Ecology 47:62-70. http://dx.doi.org/10.1111/j.1365-2028.2008.01051. 